\title{
Lipoic acid decreases peritoneal adhesion formation in a rat uterine scar model
}

\author{
Lipoik asitin deneysel sıçan modelinde peritoneal adezyon oluşumunu azalttcı etkisi \\ Serap Cilaker Mıcılı1 , Aslı Göker², Oya Sayın², Pınar Akokay', Bekir Uğur Ergürl \\ 'Department of Histology and Embryology, Dokuz Eylül University Faculty of Medicine, Izmir, Turkey \\ ${ }^{2}$ Department of Obstetrics and Gynecology, Celal Bayar University Faculty of Medicine, Manisa, Turkey \\ ${ }^{3}$ Department of Biochemistry, Dokuz Eylül University Learning Resources Center, Izmir, Turkey
}

\section{Abstract}

\begin{abstract}
Objective: To investigate the effects of lipoic acid in the prevention of postoperative pelvic adhesions by a visual scoring system and immunohistochemistry in a rat uterine horn model with full thickness injury.

Material and Methods: Twenty-eight female Wistar albino rats were randomised into four groups: uterine trauma control, 15 days and 30 days, and uterine trauma + lipoic acid, 15 days and 30 days. A full thickness defect was established by incising a segment of approximately $1.0 \mathrm{~cm}$ in length from each uterine horn, leaving the mesometrium intact. Extension and severity of the adhesions in each group were scored by a visual scoring system and evaluated immunohistochemically.
\end{abstract}

Results: Adhesion scores were $2.00 \pm 0.81,2.14 \pm 0.690 .71 \pm 0.75$, and $0.85 \pm 0.69$ for extent and $2.28 \pm 0.48,2.14 \pm 0.69,0.85 \pm 0.69$, and $1.14 \pm 0.69$ for severity in Groups 1, 2, 3 and 4, respectively. Adhesion extent and severity were significantly less for groups treated by lipoic acid but no difference was observed between long and short administration. Both Vitronectin and u-PAR staining were significantly increased in treatment groups when compared to the control group.

Conclusion: Lipoic acid was found to be effective in reducing postoperative adhesion formation in a rat model.

(J Turkish-German Gynecol Assoc 2013; 14: 76-80)

Key words: Lipoic acid, adhesion, rat, uterine scar, full thickness uterine injury

Received: 12 March, 2013

Accepted: 08 April, 2013
Özet

Amaç: Tam kat uterus hasarı yapılmış deneysel sıçan modelinde lipoik asitin postoperatif pelvik adezyonlar üzerindeki etkisinin incelenmesi amaçlanmıştır.

Gereç ve Yöntemler: Yirmi sekiz dişi Wistar albino sıçan dört gruba randomize edildi. Uterin hasar grubu kontrol, 15 gün ve 30 gün, uterin hasar + lipoik asit grubu 15 ve 30 gün. Tam kat uterin hasar her bir uterin boynuzdan $1.0 \mathrm{~cm}$ uzunlukta, mezometriyumu salim bırakarak insizyon yapılarak ve sütüre edilerek oluşturuldu. Adezyonların yaygınlığı ve şiddeti görsel skorlama sistemi ile ve immunohistokimyasal olarak yapıldı.

Bulgular: Adezyon skorları grup 1, 2, 3 ve 4 için sırasıyla yaygınlık: $2.00 \pm 0.81,2.14 \pm 0,690.71 \pm 0.75,0.85 \pm 0.69$ ve şiddet: $2.28 \pm 0.48$, $2.14 \pm 0.69,0.85 \pm 0.69,1.14 \pm 0.69$ olarak belirlendi. Adezyon yaygınlık ve şiddeti lipoik asit ile tedavi edilen grupta anlamlı olarak daha azdı ancak kısa veya uzun süreli kullanım arasında fark yoktu. Hem Vitronectin hem u-Par boyanması tedavi grubunda kontrole göre anlamlı olarak artmıştı.

Sonuç: Lipoik asit deneysel sıçan modelinde postoperatif adezyon oluşumunu önlemede etkili bulundu.

(J Turkish-German Gynecol Assoc 2013; 14: 76-80)

Anahtar kelimeler: Lipoik asit, adezyon, sıçan, uterus hasarı, tam kat uterin hasar

Geliş Tarihi: 12 Mart 2013

Kabul Tarihi: 08 Nisan 2013

\section{Introduction}

The process of incision, cauterisation and suturing during surgery inevitably results in tissue healing and postoperative peritoneal adhesions, which may lead to female infertility, chronic abdominal pain or bowel obstruction (1,2). Safe surgical entry into the abdomen is difficult in subsequent interventions and the risk of intestinal injury, haemorrhage and inadequate site exposure is increased. Minimalising tissue trauma, the avoidance of foreign materials and prophylaxis for infection are common measures against adhesion formation. There are numerous studies on developing agents such as barrier materials, hormones and their agonist/antagonists, hyaluronic acid, fibrinolytic agents, non-steroidal antiinflammatory drugs and antioxidants to prevent postoperative adhesion formation (3-7).

Women with leiomyoma uteri who wish to preserve their uterus undergo myomectomy operations; approximately 65,000 myomectomies are performed annually in the USA (8). Haemostasis may fail during myomectomy, resulting in postoperative adhesions impairing fertility (9). The caesarean rate for the USA is reported as $30.3 \%$; this many uterine cavities are exposed during surgery and are then sutured (10). These two frequent operations contribute to the risk of 
peritoneal adhesions. Adhesion formation following uterine scarring in animal experiments has not been reported to date. In this study, we used a rat model resembling myomectomy or caesarean section with uterine scarring and suturing and tested the effect of Lipoic Acid (LA) on postoperative peritoneal adhesion formation.

Free radicals, namely superoxides, peroxides and hydroxyl radicals, are mediators of inflammation inducing adhesions by cellular membrane damage. Antioxidants such as methylene blue, vitamin $\mathrm{E}$ and $\mathrm{N}$-acetyl cysteine have been reported to decrease development of peritoneal adhesions (7, 11, 12). There are few studies to our knowledge investigating the effect of LA in the prevention of adhesion formation. In this study, we aim to evaluate the effects of LA in the prevention of postoperative pelvic adhesions. To rule out subjective evaluation we have used both a visual scoring system and immunohistochemically we have used the wound healing markers, urokinase plasminogen activator (u-PAR) and vitronectin in a rat uterine horn model with full thickness injury of the myometrium.

\section{Material and Methods}

Twenty-eight female, non-pregnant Wistar albino rats were used; all experiments were performed in accordance with the guidelines provided by the Experimental Animal Laboratory and approved by the Animal Care and Use Committee of Dokuz Eylül University Faculty of Medicine. The rats weighed approximately 200-250 g, were housed three animals to a cage under standard laboratory conditions with a day cycle of 14 hours light and had free access to food and water. The rats were randomly assigned to one of four study groups: Group 1, uterine scar group (15 days) $(n=7)$; Group 2, uterine scar group (30 days) $(n=7)$; Group 3, uterine scar+LA therapy (15 days) $(n=7)$; and Group 4, uterine scar+LA (30 days) $(n=7)$.

To standardise the hormonal status of the rats, menstrual cycle was determined by vaginal smear and the experiment was done on day of the dioestrus phase. Experimental design was modified the full-thickness injury model described in 2012 by Lin et al. (13) All rats were anaesthetised by intraperitoneal injection of ketamine and xylazine $(35 \mathrm{mg} / \mathrm{kg})$. The first incision was made in the abdominal wall of each rat under sterilised conditions. Then a full-thickness defect was created by incising a segment of approximately $1.0 \mathrm{~cm}$ in length from each uterine horn, leaving the mesometrium intact (Figure 1). The margins of the uterine defect were marked with a 4-0 nylon line. The abdominal incision was closed in two layers with a monofilament $3 / 0$ polyglactin suture for the peritoneum and $2 / 0$ polyglactin suture for the skin. The operation time did not exceed 15 minutes and all animals recovered without any complications or infections. All animals were treated with an intramuscular injection of penicillin ( 80.000 units/100 $\mathrm{mg}$ ) for 3 days after the surgery.

Alpha lipoic acid (Sigma, St Louis, MO, USA) was prepared by mixing $100 \mathrm{mg} / \mathrm{kg}$ with sterile saline in a dark bottle and adding $1 \mathrm{M} \mathrm{NaOH}$ until the suspension dissolved. The $\mathrm{pH}$ was adjusted to 7.4 by adding $1 \mathrm{M} \mathrm{HCl}$. Fresh LA solution was administered by oral gavage for either 15 or 30 days after uterine scarring.

After 15 or 30 days according to the study groups, the animals were anaesthetised, relaparatomy was performed, the extent and severity of intraabdominal adhesions were recorded and animals were sacrificed. All uterine horns of each rat in all study groups were evaluated separately (total 14 horns).

An author blinded to the medication status of the rats performed the visual assessment of adhesions. A published scoring system was used (14). The extent was evaluated as 0 for no adhesions, 1 for $25 \%$ of adhesions of the traumatised area, 2 for $50 \%$ of adhesions of the traumatised area and 3 for total involvement. The severity scores were 0 for no resistance to separation, 1 when minimal dissection was required and 3 for sharp dissection.

Uterine horns were fixed in neutral formalin fluid, dehydrated in graded series with ethanol and water, and embedded in paraffin. Serial sections 5 microns thick were collected on slides. For light microscope evaluation, haematoxylin eosin staining was performed. Streptavidin-biotin technique was used for immunostaining with u-PAR (rabbit anti-rat urokinase receptor IgG, 3920, American Diagnostica; $10 \mathrm{mg} / \mathrm{mL}$ concentration) and Vitronectin (ab45139, Abcam; 1/100 dilution). Following overnight incubation at $60^{\circ} \mathrm{C}$, sections were dewaxed in xylene for 20 minutes. A decreasing series of ethanol was used for rehydration and then sections were washed in distilled water followed by phosphate-buffered saline (PBS) for 10 min each. Then, they were treated with trypsin (Cat No: 00-3008 Digest All 2A, Zymed, San Francisco, CA, USA) at $37^{\circ} \mathrm{C}$ for $15 \mathrm{~min}$. To inhibit endogenous peroxidase activity, sections were delineated with a Dako pen (Dako, Glostrup, Denmark) and incubated in a solution of $3 \% \mathrm{H}_{2} \mathrm{O}_{2}$ for $15 \mathrm{~min}$. Sections were incubated with a blocking solution (Invitrogen, Histostain-Plus Broad Spectrum Cat No:

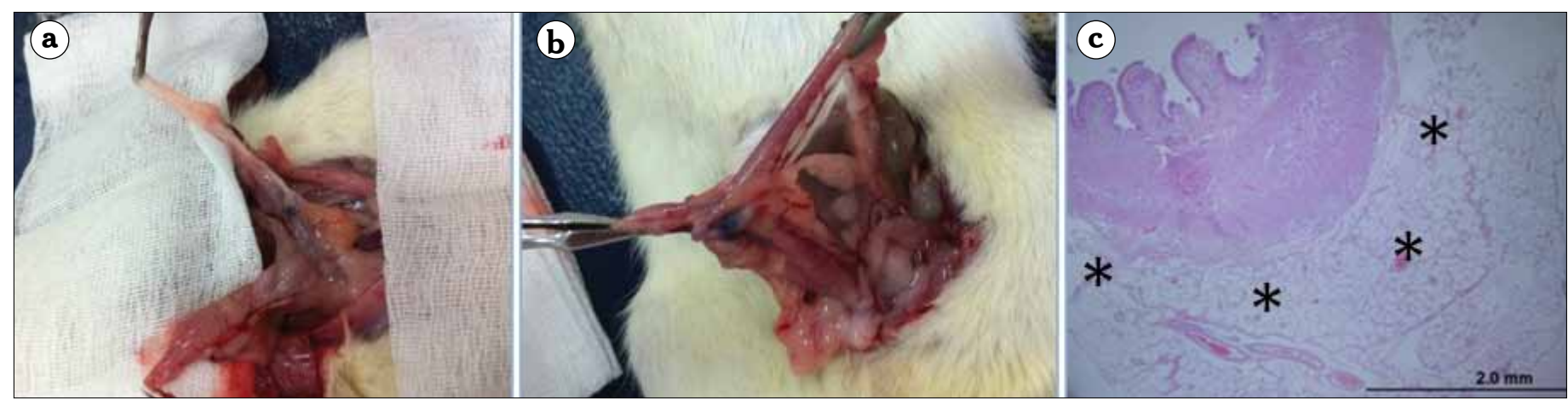

Figure 1. a, b. Macroscopic appearance of adhesion areas c. Haematoxylin-eosin evaluation of adhesion areas 
85-9043) and primary antibodies for UPAR and Vitronectin for 18 hours. Then, the sections were incubated with biotinylated IgG (Invitrogen, Histostain-Plus Broad Spectrum Cat No: 85-9043) for $30 \mathrm{~min}$, and then with streptavidin-peroxidase conjugate (Invitrogen, Histostain-Plus Broad Spectrum Cat No: 85-9043) for $30 \mathrm{~min}$. Finally, they were incubated with a solution containing DAB (Catalogue no: 1718096, Roche) to visualise immunolabelling, and counterstained with Mayer's haematoxylin (HMM199, ScyTec, Logan, Utah, USA). They were then washed with distilled water three times and mounted with entellan. All sections were examined using a light microscope.

Positive stained cells among 100 cells in 5 fields randomly chosen in each horn were counted. A total of 500 cells were counted for each horn. Statistical analysis was done using SPSS 15.0 (SPSS Inc., Chicago, USA) and Kruskal-Wallis test was applied. Results were given as mean +/- standard deviation.

\section{Results}

The extent of adhesions was 2.00 $\pm 0.81,2.14 \pm 0.690 .71 \pm 0.75$, and $0.85 \pm 0.69$ for Groups 1, 2, 3 and 4, respectively. Adhesion extent was significantly less for lipoic acid groups. When comparing 15 days and 30 days of LA administration, there was no difference. The severity of adhesions was $2.28 \pm 0.48,2.14 \pm 0.69$, $0.85 \pm 0.69$ and $1.14 \pm 0.69$ for Groups $1,2,3$ and 4, respectively. Severity of adhesions was significantly less in the LA groups, but no difference was observed between long and short administration (Table 1).

Both Vitronectin and u-PAR staining were significantly increased in LA groups when compared to the scar group. There was no significant difference between short and long LA application groups (Table 2, Figure 2).

\section{Discussion}

Postoperative pelvic adhesions may lead to complications such as extended operation time, additional blood loss and visceral damage (7) in cases of relaparatomy. Caesarean sections are the most frequently performed obstetrical operations worldwide and recurrent caesareans are difficult due to intraabdominal adhesions. Similarly, after a myomectomy there is a risk of peritoneal adhesion formation. In this study, we demonstrated that when applied orally, both short and long duration treatments with lipoic acid were effective in preventing pelvic adhesions following surgical trauma in rats. Tissue remodelling markers were used to verify the results.

The incision site of the myometrium and locations of subsequent suturing are areas where wound healing takes place. Healing is a result of proliferation and regeneration of the mesothelial cell layer and fibrinolysis producing a peritoneal scar (15). Adhesions are primarily the result of this scar. An increase in oxidative stress and the formation of reactive oxygen species (ROS) play an important role in the pathophysiology of adhesion formation. Antioxidants such as methylene blue, vitamin $\mathrm{E}$ and $\mathrm{N}$-acetyl cysteine have been reported to decrease development of peritoneal adhesions $(7,11,12)$. Alpha LA and its metabolites are antioxidant and, when in contact with free radicals, oxidation takes place (16).

There are several experimental models for producing peritoneal adhesions in laboratory animals: the damaged uterine horn model by electrocautary or scraping, caecal abrasion, peritonitis model and the bowel anastomosis model (4, 17-20). The traumatisation of the uterine horn is widely used to mimic abdominal surgery; however, in the most frequent gynaecology

Table 1. Extent and severity of adhesion

\begin{tabular}{|c|c|c|c|}
\hline Group & $\begin{array}{l}\text { Uterine horn number } \\
\quad(\text { mean } \pm \text { SD) }\end{array}$ & $\begin{array}{l}\text { Adhesion extent } \\
\text { (mean } \pm \text { SD) }\end{array}$ & $\begin{array}{l}\text { Adhesion severity } \\
\quad(\text { mean } \pm \text { SD) }\end{array}$ \\
\hline Uterine Scar Group (15d) & 14 & $2.00 \pm 0.81$ & $2.28 \pm 0.48$ \\
\hline Uterine Scar Group (30d) & 14 & $2.14 \pm 0.69$ & $2.14 \pm 0.69$ \\
\hline Uterine Scar Group+LA therapy (15d) & 14 & $0.71 \pm 0.75^{*}$ & $0.85 \pm 0.69^{*}$ \\
\hline Uterine Scar Group+LA therapy (30d) & 14 & $0.85 \pm 0.69 * *$ & $1.14 \pm 0.69 * *$ \\
\hline \multicolumn{4}{|c|}{$\begin{array}{l}\text { Uterine Scar } 15 \mathrm{~d} \text { vs. Uterine Scar } 30 \mathrm{~d}(\mathrm{p}=0.72, p=0.70) \text { for extent and severity; (*) Uterine Scar } 15 \mathrm{~d} \text { vs. Uterine Scar } 15 \mathrm{~d}+\mathrm{LA}(\mathrm{p}=0.01, \mathrm{p}=0.003) \text { for } \\
\text { extent and severity; }(* *) \text { Uterine Scar } 30 \mathrm{~d} \text { vs. Uterine Scar } 30 \mathrm{~d}+\mathrm{LA}(\mathrm{p}=0.009, p=0.024) \text { for extent and severity, Uterine Scar } 15 \mathrm{~d}+\mathrm{LA} \text { vs. Uterine Scar } \\
30 \mathrm{~d}+\mathrm{LA}(\mathrm{p}=0.674, \mathrm{p}=0.431) \text { for extent and severity }\end{array}$} \\
\hline
\end{tabular}

Table 2. Immunohistochemical staining of Vitronectin and u-PAR of adhesion tissue

\begin{tabular}{|c|c|c|}
\hline Group & $\begin{array}{c}\text { Vitronectin } \\
(\text { mean } \pm S D)\end{array}$ & $\begin{array}{c}\text { u-PAR } \\
(\text { mean } \pm S D)\end{array}$ \\
\hline Uterine Scar Group (15d) & $11.42 \pm 2.50 *$ & $13.7 \pm 2.05^{*}$ \\
\hline Uterine Scar Group (30d) & $21.43 \pm 6.57$ & $19.4 \pm 3.86$ \\
\hline Uterine Scar Group+LA therapy (15d) & $39.14 \pm 9.51 * *$ & $40.7 \pm 8.42 * *$ \\
\hline Uterine Scar Group+LA therapy (30d) & $42.14 \pm 8.98 * * *$ & $43.5 \pm 6.72^{* * *}$ \\
\hline \multicolumn{3}{|c|}{$\begin{array}{l}\text { (*) Uterine Scar } 15 \mathrm{~d} \text { vs. Uterine Scar } 30 \mathrm{~d}(\mathrm{p}=0.001, \mathrm{p}=0.011) \text { for Vitronectin and u-PAR immunostaining; (**) Uterine Scar } 15 \mathrm{~d} \text { vs. Uterine Scar } 15 \\
\mathrm{~d}+\mathrm{LA}(\mathrm{p}=0.001, \mathrm{p}=0.001) \text { Vitronectin and } \mathrm{u}-\mathrm{PAR} \text { immunostaining; }(* * *) \text { Uterine Scar } 30 \mathrm{~d} \text { vs. Uterine Scar } 30 \mathrm{~d}+\mathrm{LA}(\mathrm{p}=0.004, \mathrm{p}=0.001) \text { for Vitronectin } \\
\text { and } \mathrm{u}-\mathrm{PAR} \text { immunostaining, Uterine Scar } 15 \mathrm{~d}+\mathrm{LA} \text { vs. Uterine Scar } 30 \mathrm{~d}+\mathrm{LA}(\mathrm{p}=0.902, \mathrm{p}=0.456) \text { for Vitronectin and u-PAR immunostaining }\end{array}$} \\
\hline
\end{tabular}




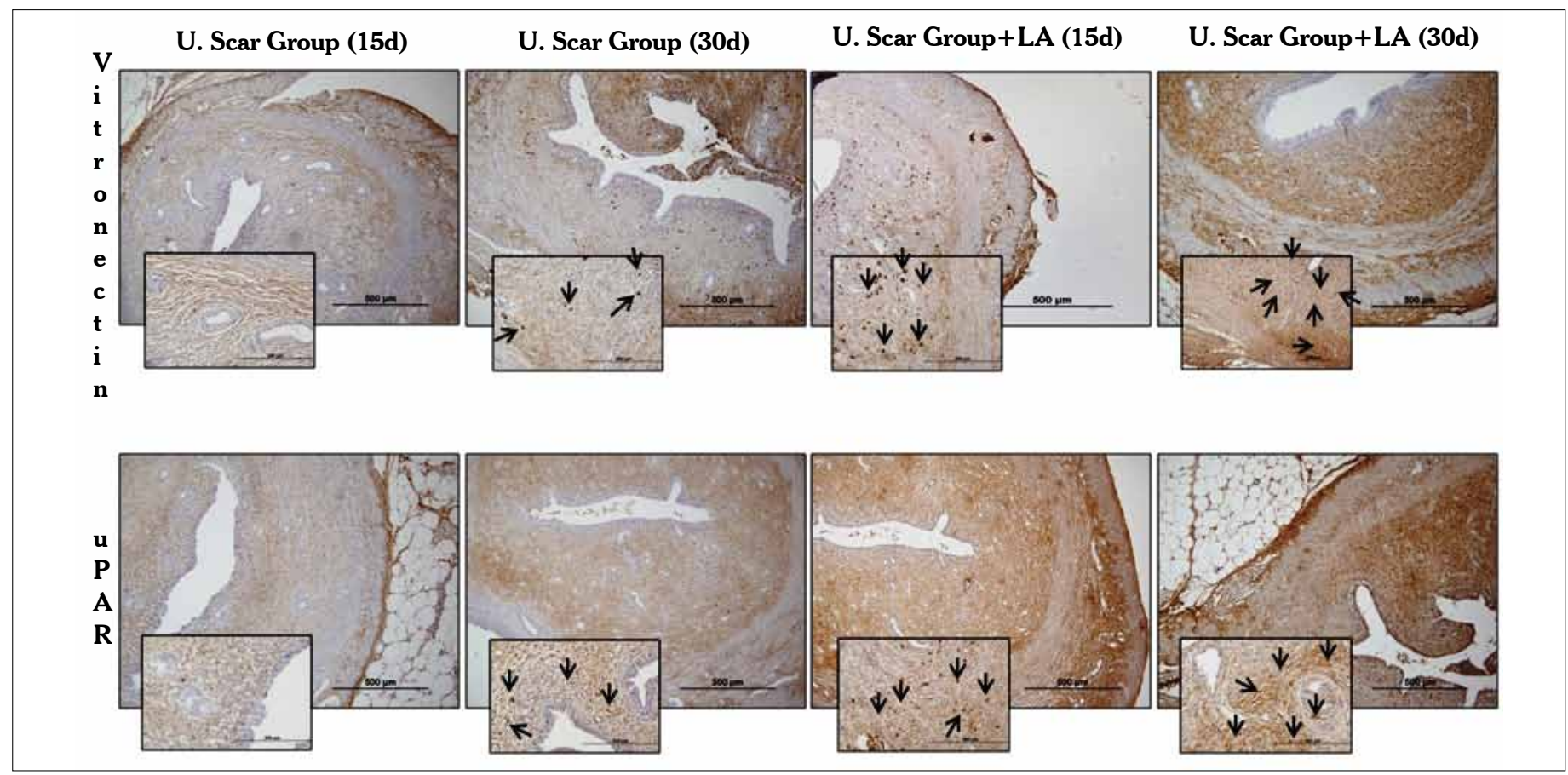

Figure 1. Staining of vitronectin and u-PAR in uterine scar groups of control and LA after 15 and 30 days (arrows)

and obstetrics operations there is a full thickness cut through the uterine wall. Therefore, we have chosen a new model to form adhesions. We cut the uterine horns using full layer thickness and then sutured the incision resembling a caesarean section or myomectomy where the uterine cavity is exposed. Tissue remodelling and a normal healing process require plasminogen activators to form plasmin which will play a role in fibrinolysis. Insufficiency in fibrinolysis after surgery may lead to fibrin deposition causing adhesions. Urokinase plasmin activator binds to its receptor u-PAR which was used in the present study. Vitronectin on the other hand activates plasminogen activators and integrins and the balance of these molecules is important in regeneration $(21,22)$.

ROS are shown to be involved in adhesion formation after surgery. There is an increase of free radical activity of superoxide anions, xanthine oxidase and MDA $(23,24)$. The surgical area is a local hypoxic environment leading to an ischemia/reperfusion process resulting in a decrease of free radical scavenger levels. Restoration of these free radical scavengers have been shown to prevent adhesion formation in animal studies with induced intestinal ischemia (25). During peritoneal healing, oxidative stress increases and a positive correlation between the level of oxidative stress and the severity of adhesions has been demonstrated $(26,27)$. Postsurgical adhesion formation was reduced by the administration of antioxidants such as vitamin $\mathrm{E}$, selenium or resveratrol in previous studies $(5,12,28)$. Ozler et al. (29) have shown the existence of oxidative stress in a rat model with caecal trauma and a decrease after the application of lipoic acid. Even though the method of adhesion formation induction differs from our study, it supports our hypothesis that LA is effective in preventing postsurgical adhesions.

Lipoic acid is used in the therapy of diabetes, atherosclerosis, neurodegenerative processes, joint diseases or acquired immune deficiency syndrome $(16,30)$. It has a low redox potential and thus participates in reactions neutralising ROS, and reduces the oxidised forms of other antioxidants. Another advantage of LA is the fact that it is soluble in water and in fats (16). This is the first experimental study that combines a new method for adhesion formation, an antioxidant molecule (lipoic acid) and immunohistochemical methods to evaluate the results objectively.

Most studies about postoperative adhesion formation and prevention use visual evaluation methods and remain as subjective results. The authors have contributed to the literature on adhesion evaluation via an immunohistochemical method using u-PAR and vitronectin markers for objective evaluation (4). In the present study, this method is used again to confirm the anti-adhesion effect of lipoic acid administration after surgical intervention mimicking caesarean section or myomectomy. A distinctive increase in both tissue regeneration markers has been observed in animals treated with LA. The present results suggest a possible preventive effect of LA on postoperative adhesions after full thickness uterine trauma with minimal side effects and minimal cost.

Ethics Committee Approval: Ethics committee approval was received for this study from the Animal Care and Use Committee of Dokuz Eylül University Faculty of Medicine.

Informed Consent: N/A.

Peer-review: Externally peer-reviewed.

Author contributions: Concept - S.C.M., A.G.; Design - S.C.M, A.G., B.U.E.; Supervision - O.S., B.U.E.; Resource - S.C.M., B.U.E.; Materials - S.C.M., O.S., P.A.; Data Collection\&/or Processing S.C.M., A.G.; Analysis\&/or Interpretation - S.C.M., A.G., B.U.E.; Literature Search - S.C.M., A.G., P.A.; Writing - S.C.M., A.G.; Critical Reviews - O.S., B.U.E. 


\section{Conflict of Interest: No conflict of interest was declared by the} authors.

\section{Financial Disclosure: No financial disclosure was declared by the authors.}

\section{References}

1. Practice Committee of American Society for Reproductive Medicine in collaboration with Society of Reproductive Surgeons. Pathogenesis, consequences, and control of peritoneal adhesions in gynecologic surgery. Fertil Steril 2008; 90: S144-9. [CrossRef]

2. Cheong YC, Laird SM, Li TC, Shelton JB, Ledger WL, Cooke ID. Peritoneal healing and adhesion formation/reformation. Hum Reprod Update 2001; 7: 556-66. [CrossRef]

3. Haney AF, Doty E. A barrier composed of chemically cross-linked hyaluronic acid (Incert) reduces postoperative adhesion formation. Fertil Steril 1998; 70: 145-51. [CrossRef]

4. Tamay AG, Guvenal T, Micili SC, Yildirim Y, Ozogul C, Koyuncu FM, et al. Evaluation of the effects of gonadotropin-releasing hormone antagonist (GnRH-ant) and agonist (GnRH-a) in the prevention of postoperative adhesion formation in a rat model with immunohistochemical analysis. Fertil Steril 2011; 96: 1230-3. [CrossRef]

5. Cheung JP, Tsang HH, Cheung JJ, Yu HH, Leung GK, Law WL. Adjuvant therapy for the reduction of postoperative intra-abdominal adhesion formation. Asian J Surg 2009; 32: 180-6. [CrossRef]

6. Greene AK, Alwayn IP, Nose V, Flynn E, Sampson D, Zurakowski $\mathrm{D}$, et al. Prevention of intra-abdominal adhesions using the antiangiogenic COX-2 inhibitor celecoxib. Ann Surg 2005; 242: 140-6. [CrossRef]

7. Chu DI, Lim R, Heydrick S, Gainsbury ML, Abdou R, D'Addese L, et al. N-acetyl-l-cysteine decreases intra-abdominal adhesion formation through the upregulation of peritoneal fibrinolytic activity and antioxidant defenses. Surgery 2011; 149: 801-12 [CrossRef]

8. Lumsden MA. Embolization versus myomectomy versus hysterectomy: which is best, when? Hum Reprod 2002; 17: 253-9. [CrossRef]

9. Bajekal N, Li TC. Fibroids, infertility and pregnancy wastage. Hum Reprod Update 2000; 6, 614-20. [CrossRef]

10. The Global Numbers and Costs of Additionally Needed and Unnecessary Caesarean Sections Performed per Year: Overuse as a Barrier to Universal Coverage Luz Gibbons, José M. Belizán, Jeremy A Lauer, Ana P Betrán, Mario Merialdi and Fernando Althabe World Health Report (2010) Background Paper, 30

11. Mahdy T, Mohamed G, Elhawary A. Effect of methylene blue on intra-abdominal adhesion formation in rats. Int J Surg 2008; 6: 452-5. [CrossRef]

12. Durmus AS, Yildiz H, Yaman I, Simsek H. Efficacy of vitamin E and selenium for the prevention of intra-abdominal adhesions in rats: uterine horn models. Clinics (Sao Paulo) 2011; 66: 1247-51. [CrossRef]

13. Lin N, Li X, Song T, Wang J, Meng K, Yang J, et al. The effect of collagen-binding vascular endothelial growth factor on the remodeling of scarred rat uterus following full-thickness injury. Biomaterials 2012; 33: 1801-7. [CrossRef]

14. Linsky CB, Diamond MP, Cunningham T, Constantine B, DeCherney $\mathrm{AH}$, diZerega GS. Adhesion reduction in the rabbit uterine horn model using an absorbable barrier, TC-7. J Reprod Med 1987; 32: 17-20.

15. Duron JJ. Postoperative intraperitoneal adhesion pathophysiology. Colorectal Dis 2007; 9: 14-24. [CrossRef]

16. Bilska A, Włodek L. Lipoic acid - the drug of the future? Pharmacol Rep 2005; 57: 570-7.

17. Kahyaoglu S, Timur H, Kaba M, Kahyaoglu I, Sirvan L, Cicek MN. Prevention of adhesion formation in Wistar-albino rats by increased bowel movements achieved with oral Ricinus oil use for 8 days postoperatively: an experimental study. Eur J Obstet Gynecol Reprod Biol 2012; 165: 337-41. [CrossRef]

18. Peyton CC, Keys T, Tomblyn S, Burmeister D, Beumer JH, Holleran $\mathrm{JL}$, et al. Halofuginone infused keratin hydrogel attenuates adhesions in a rodent cecal abrasion model. J Surg Res 2012; 178: 54552. [CrossRef]

19. Kalaycı MU, Eroğlu HE, Kubilay D, Soylu A, Sancak B, Uğurluoğlu C, et al. The effects of methylene blue on adhesion formation in a rat model of experimental peritonitis. Ulus Travma Acil Cerrahi Derg 2011; 17: 205-9. [CrossRef]

20. Lauder CI, Garcea G, Strickland A, Maddern GJ. Use of a modified chitosan-dextran gel to prevent peritoneal adhesions in a rat model. J Surg Res 2011; 171: 877-82. [CrossRef]

21. Eming SA, Brachvogel B, Odorisio T, Koch M. Regulation of angiogenesis: wound healing as a model. Prog Histochem Cytochem 2007; 42: 115-70. [CrossRef]

22. Schvartz I, Seger D, Shaltiel S. Vitronectin. Int J Biochem Cell Biol 1999; 31: 539-44. [CrossRef]

23. Alpay Z, Saed GM, Diamond MP. Female infertility and free radicals:Potential role in adhesions and endometriosis. J Soc Gynecol Investig 2006; 13: 390-8. [CrossRef]

24. Bentes de Souza AM, Rogers MS, Wang CC, Yuen PM, Ng PS. Comparison of peritoneal oxidative stress during laparoscopy and laparotomy. J Am Assoc Gynecol Laparosc 2003; 10: 65-74. [CrossRef]

25. Yildiz H, Durmus AS, Simsek H. Surgery-induced changes in red blood cell and plasma lipid peroxidation, enzymatic and nonenzymatic antioxidants, and blood hematology of female rats: protective role of methylene blue and vitamin E. Eur J Obstet Gynecol Reprod Biol 2011; 155: 89-93. [CrossRef]

26. ten Raa S, van den Tol MP, Sluiter W, Hofland LJ, van Eijck $\mathrm{CH}$, Jeekel $\mathrm{H}$. The role of neutrophils and oxygen free radicals in postoperative adhesions. J Surg Res 2006; 136: 45-52. [CrossRef]

27. Ara C, Kirimlioglu H, Karabulut AB, Coban S, Hascalik S, Celik O, et al. Protective effect of melatonin against oxidative stress on adhesion formation in the rat cecum and uterine horn model. Life Sci 2005; 77: 1341-50. [CrossRef]

28. Sogutlu G, Karabulut AB, Ara C, Cinpolat O, Isik B, Piskin T, et al The effect of resveratrol on surgery-induced peritoneal adhesions in an experimental model. Cell Biochem Funct 2007; 25: 217-20.

29. Özler M, Ersöz N, Özerhan İH, Topal T, Öter Ş, Korkmaz A. The effect of alpha-lipoic acid in the prevention of peritoneal adhesions. Turk J Gastroenterol 2011; 22: 190-4.

30. Singh U, Jialal I. Alpha-lipoic acid supplementation and diabetes. Nutr Rev 2008; 66: 646-57. [CrossRef] 